\title{
A Review on Solar Drying of Fish
}

\author{
Nasreen S. Al-Mahruqi and Abdulrahim M. Al-Ismaili*
}

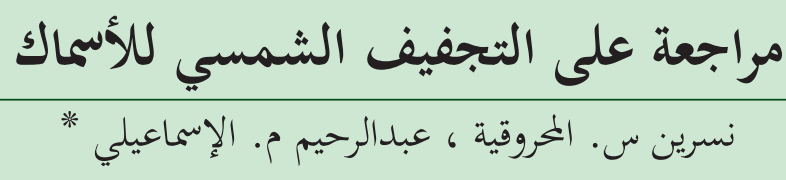

AbSTRACT. Oman is one of the major fish producers in this region. Fish is highly perishable, therefore different preservation techniques, such as smoking, drying, chilling, brining and freezing are being used. Solar drying is one of the most popular technique due to its simplicity and low cost as compared to other techniques. This study aimed to review the different types of solar drying techniques and highlighted the quality measures of solar dried fish. Solar drying techniques can be divided into three types: open-sun drying, direct and indirect solar drying. The open-sun drying is the most adoptable method because it is the cheapest preservation technique. However, this technique has several drawbacks, such as the uncertainty of weather, large implementation area, required time, poor drying rate, high labor costs, possible attack by insects, microorganism and birds, and contaminated with dust and foreign materials. Solar dryers, on the other hand, overcome the most of drawbacks associated with open-sun drying. They have shorter drying time and higher drying rate, and at the same time these enhance the physical properties of dried fish. For better understanding of the drying processes many regression models were used and the exponential model was found to be the best fitted model describing the drying behavior. Fish possesses good nutritional value due to higher amount of proteins, lipids and ash contents. For higher shelf life, fish has to meet certain characteristics with respect to $\mathrm{pH}$, water activity, microbial load, total volatile base nitrogen (TVB-N), trimethylamine nitrogen (TMA-N) and enzymatic autolysis. For a very good quality, the $\mathrm{pH}$ must be ranged from 6.0-6.9 and the water activity must be lower than 0.6. The TVB-N and TMA-N are the indicators of spoilage and their upper acceptable limits are $10-15 \mathrm{mg} / 100 \mathrm{~g}$ and $35-40 \mathrm{mg} / 100 \mathrm{~g}$, respectively. Total plate count (TPC) and total fungal count (TFC) are two attributes used to assess the microbiological quality of fish products. The autolysis changes in the fish lead to spoilage as a result of the production of biogenic amines and microbial growth. Studying the health aspect of dried fish is very important for the human body to obtain a greater proportion of proteins and important substances away from the harmful chemicals that may appear in traditional draying technique.

KEYWORDS: Solar drying techniques, fish, quality

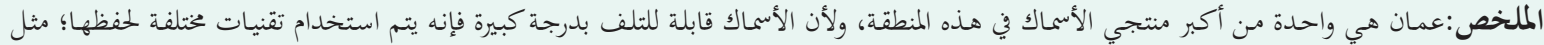

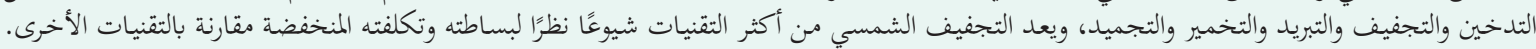

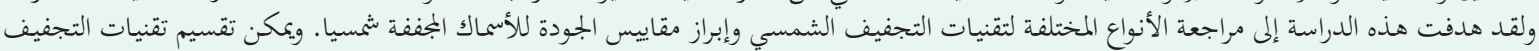

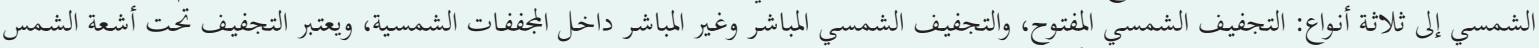

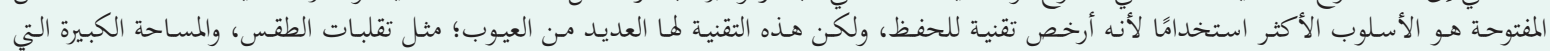

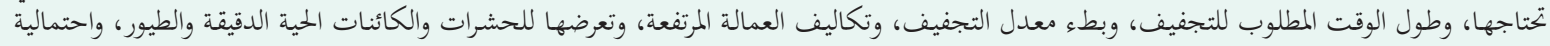

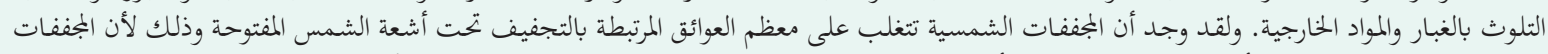

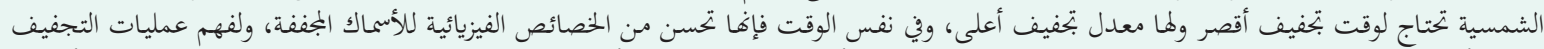

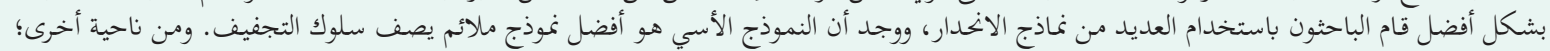

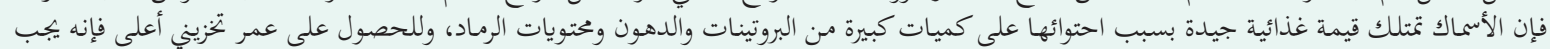

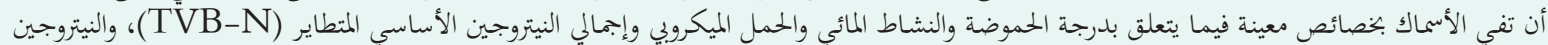

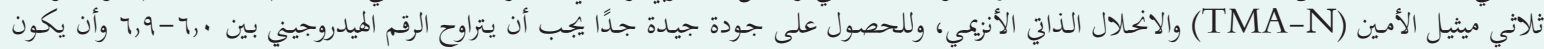

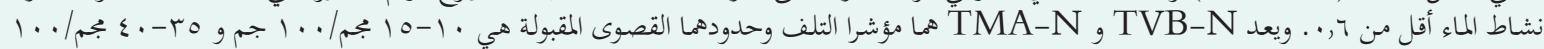

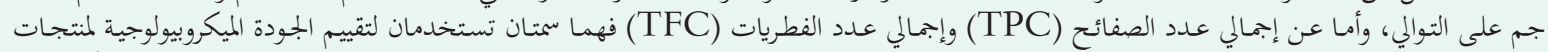

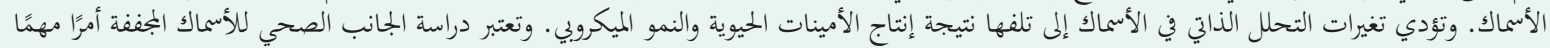

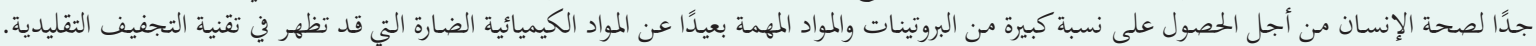

$$
\text { الكلمات المفتاحية: طرق التجفيف التقليدية، الأسماك، الجودة. }
$$

\section{Introduction}

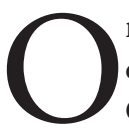

man is considered one of the largest fish producers and consumers in the Gulf Cooperation Council (FAO, 2015). Fish is a very popular food due to its high protein and nutrients content. Howev-

Abdulrahim M. Al-Ismaili**( $(\checkmark)$ abdrahim@squ.edu.om; ams.ismaili@ gmail.com, Department of Soils, Water and Agricultural Engineering, Sultan Qaboos University, Oman er, the due to the high moisture content in fish (Tiwari et al., 2009), spoilage is a critical issue facing fish producers. Because of the high spoilage rate of fish (Jain and Pathare, 2007), Ghaly et al. (2010) found that 30\% of fish is lost every year. Therefore, several techniques have been practiced to preserve fish in order to increase their shelf life and to maintain their texture, flavour and nutritional value (Ghaly et al., 2010). Smoking, drying, chilling, brining and freezing are among the common- 
ly-practiced techniques for fish preservation (Ghaly et al., 2010). However, fish drying is the most popular technique (Jain and Pathare, 2007; Sahu et al., 2016), which is achieved using different approaches such as solar, electrical, spray and mechanical drying methods (Prakash and Kumar, 2014; Singh et al., 2017). Due to the increase in the prices of fossil fuels, solar drying became the most widely-used drying method as it uses a renewable source of energy and does not rely on fossil fuel (Bala and Janjai, 2009; Prakash and Kumar, 2014). The objectives of this article were to review the different types of solar drying techniques and to highlight the quality measures of solar dried fish.

\section{Solar Drying Techniques}

Solar energy is the most abundant source of energy on the earth and consequently, it is used in many processes. Solar drying is a traditional drying process that harnesses solar energy to speed up the drying process. There are three types of solar drying techniques, which are open-sun drying, direct and indirect solar drying (Sahu et al., 2016). The most popular technique is drying by the direct exposure to sun which is considered the cheapest technique as it does not demand a significant infrastructure and operational costs (Jain and Pathare, 2007) (Figure 1). When the product is exposed to sun, its temperature increases due to heat absorption, which in turn leads to moisture reduction, i.e. drying.

In the direct solar drying technique, the product is placed inside a structure that is covered with a transparent material, such as plastic and glass (Figure 2). This kind of structure traps the solar heat (greenhouse effect) as it allows shortwave radiation to pass and captures the longwave radiation (Singh et al., 2017), i.e. causing higher air temperatures and thus, faster drying (Sahu et al., 2016). In this technique, drying rate can be additionally increased by the use of fans to bring dryer air over the products and this technique is known as "forced convective" direct drying (Singh et al., 2017).

In the indirect drying techniques (Figure 3), products are not exposed to direct sun light but instead, ambient air is heated by solar radiation via a solar collector and then the hot air flows over the products. The air is circulated in this technique either by natural convection (i.e. indirect dryer under passive mode) or by the use of exhaust fans. In the former, ambient air enters to the solar collector through a lower vent and then the hot air leaves to the drying chamber through a higher vent, i.e. thermosyphic effect (Prakash and Kumar, 2014). In the latter, exhaust fans located at the outlet vent are used to move the air stream and this technique is known as forced convection indirect solar drying (Sahu et al., 2016). The forced convection dryer is more suitable for products with high moisture content while natural convection is suitable for low moisture products (Sahu et al., 2016; Singh et al., 2017). Prakash and Kumar (2014) found that the convective mass transfer coefficient in the forced convection mode was double than that in the natural convection mode. As illustrated in Figures 2 and 3, the structure of direct and indirect solar dryers is similar to the structure of greenhouses, which may explain the reason why these dryers are also called "greenhouse dryers".

The efficiency of solar dryers is enhanced by the integration with photovoltaic (PV) systems. The use of PV-integrated solar dryers is very practical if forced convection is to be implemented in the areas where electricity is not available or not affordable (Sahu et al., 2016). In terms of solar drying performance, the greenhouse dryer is considered the best alternative to sun drying. Bala and Janjai (2009) reported that PV-integrated greenhouse solar dryers can reduce the drying time by almost $50 \%$. The shape of the greenhouse is another factor affecting the drying process. It was reported by Charters et al. (2017) that the dome shape (hemispherical) can offer the maximum utilization of solar radiation and the even-span shape is utilized for proper air mixing.
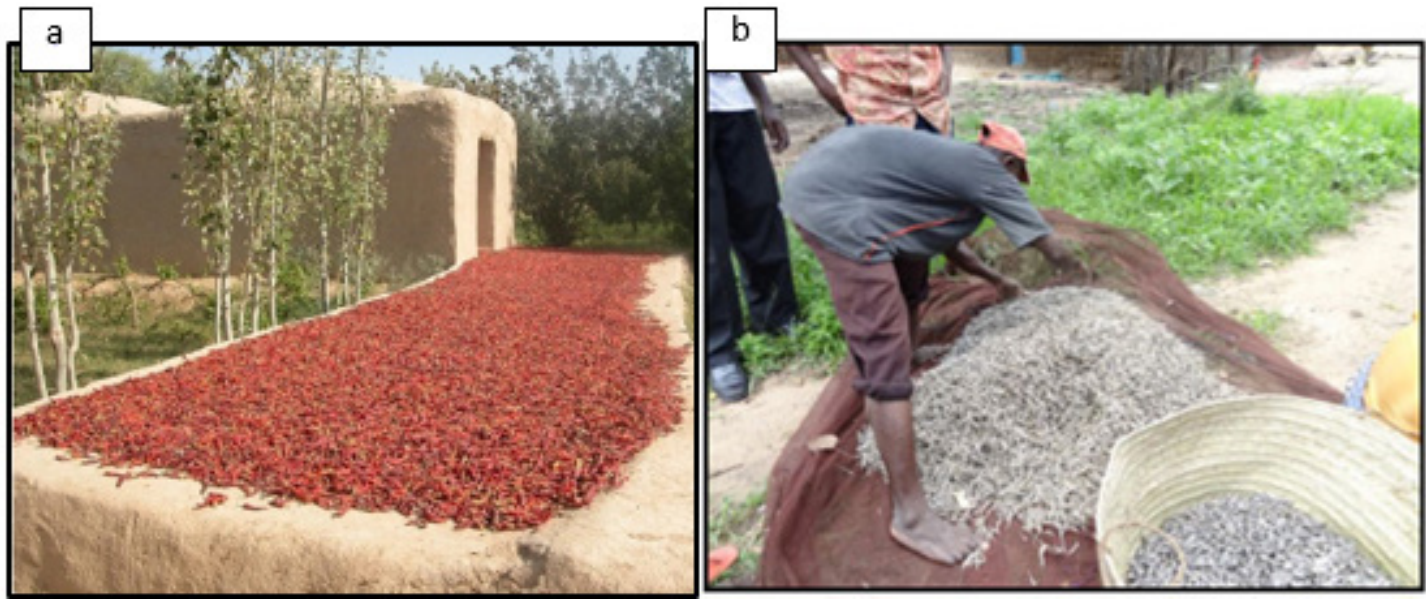

Figure 1. Solar drying by direct sun exposure for (a) Red chili pepper (Walters and Jha, 2016), and (b) Fish (Ochieng et al., 2015). 


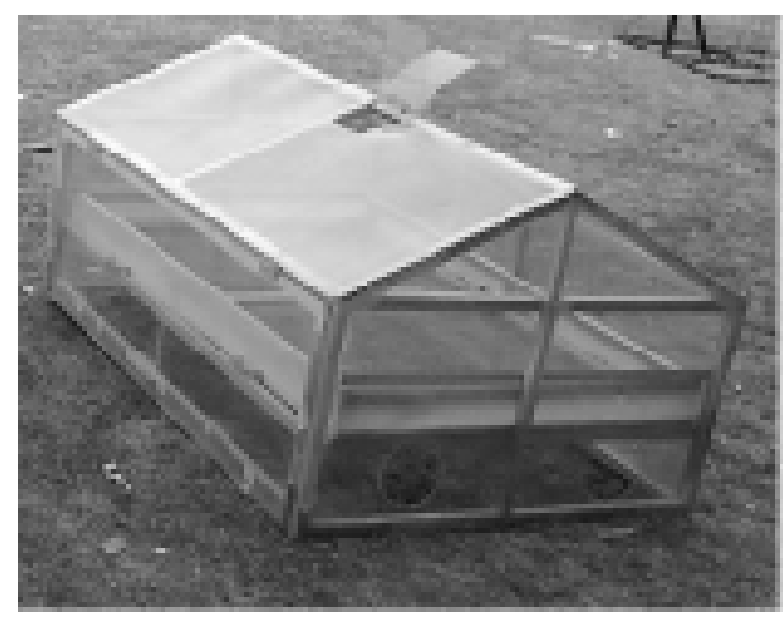

Figure 2. Direct solar dryer (Singh et al., 2017).

\section{Advantages and Disadvantages of Solar Drying}

Solar radiation is an abundant, eco-friendly and inexhaustible source of energy (Ghaly et al., 2010). Hence, it represents the cheapest way to preserve food (Jain and Pathare, 2007). Nevertheless, there are many disadvantage related to open-sun drying method, such as the uncertainties of weather, requirement of large implementation area, time-consuming, poor drying rate, high labour costs, attacking by insects, microorganism and birds, and mixing with dust and foreign materials (Jain and Pathare, 2007; Al Rawahi et al., 2013; Martunis, 2013; Sontakke and Salve, 2015). Mansur et al. (2013) found that, during open-sun drying, some fish samples contained a large amount of debris from the poor quality underlying material and the dried samples have undergone surplus drying or inappropriate drying and handling. However, some of these limitations, e.g. time-consuming, insect attacks and dust contamination, can be

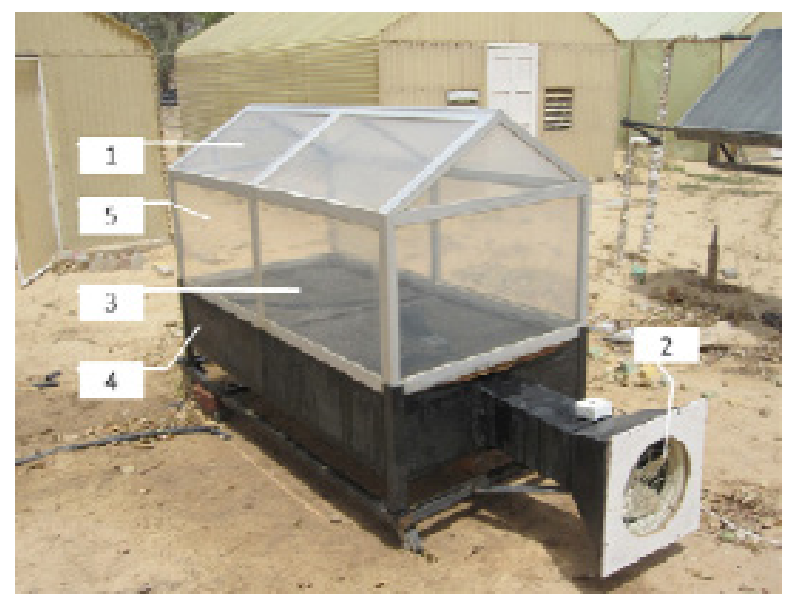

Figure 3. Indirect forced convection solar dryer; 1 : Vent , 2: Exhaust fan , 3: Heating chamber, 4: Drying chamber and 5: Glass cover with fibre (Singh et al., 2017). eliminated by the use of greenhouse dryers (Charters et al., 2017; Sontakke and Salve, 2015).

\section{Solar Fish Drying}

In many coastal areas, fish is considered a main source of food and income (Belwal et al. 2015). However, fish products are highly perishable and thus, have a short shelf life (Bala and Mondol, 2001). Drying is the most widely-used preservation technique used to overcome the spoilage problem. Because of their high market value and availability, several fish species such as ribbon fish, golden anchovies, croker, prawns, paplet and surmai are dried using solar drying techniques (Sengar et al., 2009).

In Oman, due to the high fish production and consumption, traditional sun drying techniques are widely practiced to dry a variety of fish types such as sardine, anchovy and jake mackerel (Al Bulushi et al., 2013; Al Rawahi et al., 2013). Sardine fish alone represents $80 \%$ of the total Oman small fish catching and the annual amount of dried sardine is 23000 tons, which is mainly used as a livestock feed (Al-Jufaili and Al-Jahwari, 2011; Basunia et al., 2011). Open-sun drying of fish is an old method used worldwide to dry a variety of fish types. In Oman, as an example, sardine fish (Figure 4) are traditionally dried by dispersing the fish on sandy beaches for 7 days in low ambient temperatures and 4-5 days in high temperatures (Basunia et al., 2011). This method, although widely-accepted, is associated with a substantial loss of almost $30-40 \%$ of the total dried amount due to a variety of reasons that include rain, wind, dust and contamination and consumption by animals, birds and rats (Al Rawahi et al., 2013).

Other solar drying techniques such as greenhouse dryers are implemented to overcome the drawbacks of open-sun drying. For instance, Sengar et al. (2009) used a low cost passive (natural convection) multi-shelf greenhouse solar dryer (Figure 5) to dry prawns. The fish dried inside the solar dryer were found better than the fish dried in open-sun in terms of drying time, texture and color. In a similar study, silver jewfish was dried by a natural convection solar tunnel drier in Bangladesh (Bala and Janjai, 2009). The solar dried products had better quality with a significant reduction in drying time as compared with open-sun drying. In another study, a low cost passive solar tunnel dryer (Figure 6) was developed in Oman to dry sardine, skater bream and jake mackerel (Al Rawahi et al., 2013). On the other hand, an active (forced convection) greenhouse solar dryer was used in Indonesia for drying anchovy fish (Figure 7) (Martunis, 2013). In a similar study, jewfish was dried in a hybrid solar drying system and it was found that the drying time took only $8 \mathrm{~h}$ to reduce the moisture content from 64 to $10 \%$ (Singh et al., 2017). All of the abovementioned dryers managed to reduce the drying time with increased water loss.

Several studies focused on the calculation of drying time, drying rate and the final moisture content of the 


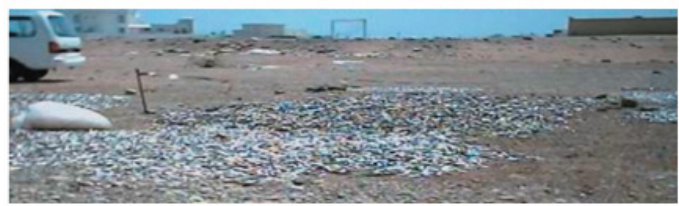

(a)

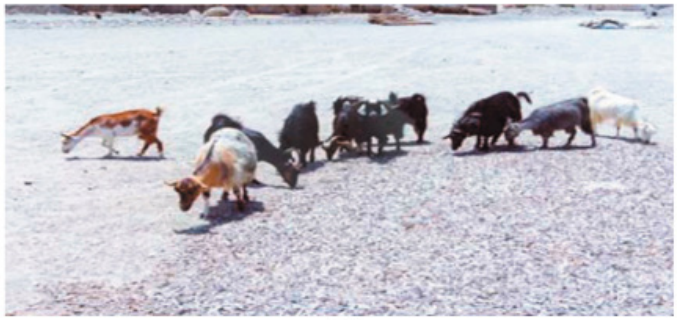

(b)

Figure 4. Traditional open-sun drying of sardine, (a) Sardine fish dispersed on a sandy beach and (b) Animals eating from the dried sardine (Al-Jufaili and Al-Jahwari, 2011).

dried fish products. For example, the drying time to reduce the initial moisture content of prawns from 75 to $16.4 \%$ in open-sun drying and to $16.5 \%$ in a low-cost passive solar dryer was 11 and $8 \mathrm{~h}$, respectively (Sengar et al., 2009). Similarly, Abraha et al. (2017) found that open-sun drying of anchovy took 5 days and inside a solar tent drier, it took only 3 days. Using a natural convective solar drier, it was found that the drier was able to reduce the initial moisture content of bayad fish flakes from $78.67 \%$ to a final moisture content of $11.41 \%$ (Babiker et al., 2014). Mustapha et al. (2014) studied five different solar driers and found that black stone-inserted glass drier showed the fastest drying rate in comparison to the plastic drier, mosquito net drier, glass drier and aluminum drier for drying African catfish and Nile tilapia. Martunis (2013) reported that the drying rate of fish using a force convection greenhouse was $3.29 \%$ per hour in a total drying time of $11 \mathrm{~h}$ while the same amount of fish took 2 days to dry in the sun. Using a parabolic-dish solar collector (Figure 8), Solomon et al. (2016) found that salted prawn and unsalted prawn required $8 \mathrm{~h}$ and $15 \mathrm{~h}$ to dry, respectively which highlights the effect of salting on the drying time. In all drying processes, the drying time increased with increasing humidity in the ambient air (Bala and Janjai, 2009). In general, the drying rate starts high at the beginning of the drying process and decreases with the reduction in moisture content (Jain and Pathare, 2007).

The solar drying technique has a great effect on the physical properties of dried fish. Under open-sun drying, (Mansur et al., 2013) compared three physical characteristics, namely, color, odor and texture, of three types of fish; labeo, channa and wallago attu. The results showed that labeo and channa fish had better quality than wallago fish which developed bitter taste, rancid odor and soft and fibrous texture. However, all three fish had brown color as compared to the fresh fish which have cream color. In a similar study the channa fish showed good physical quality as compared with wallago and glossogobius fish (Majumdar et al., 2017). Islam et al. (2012) reported differences in the physical properties of dried mola fish in a solar tunnel. The final color of the dried fish was ranging from white to light brown and the texture was firm and flexible with good odor. The overall quality of the dried mola fish was excellent as compared with the traditionally dried mola fish, where the color was brown and the texture was soft with off-odor. In general, Mustapha et al. (2014) found that the physical parameters of open-sun dried fish was the least acceptable among the fish dried in five other solar driers.

Abraha et al. (2017) reported that the physical properties, such as color, flavor, appearance, texture and odor was superior for fish dried in a solar tent drier to fish dried in open-sun. For instance, anchovy fish dried in a greenhouse dryer undergone no color change during the drying process (Martunis, 2013). Sengar et al. (2009)

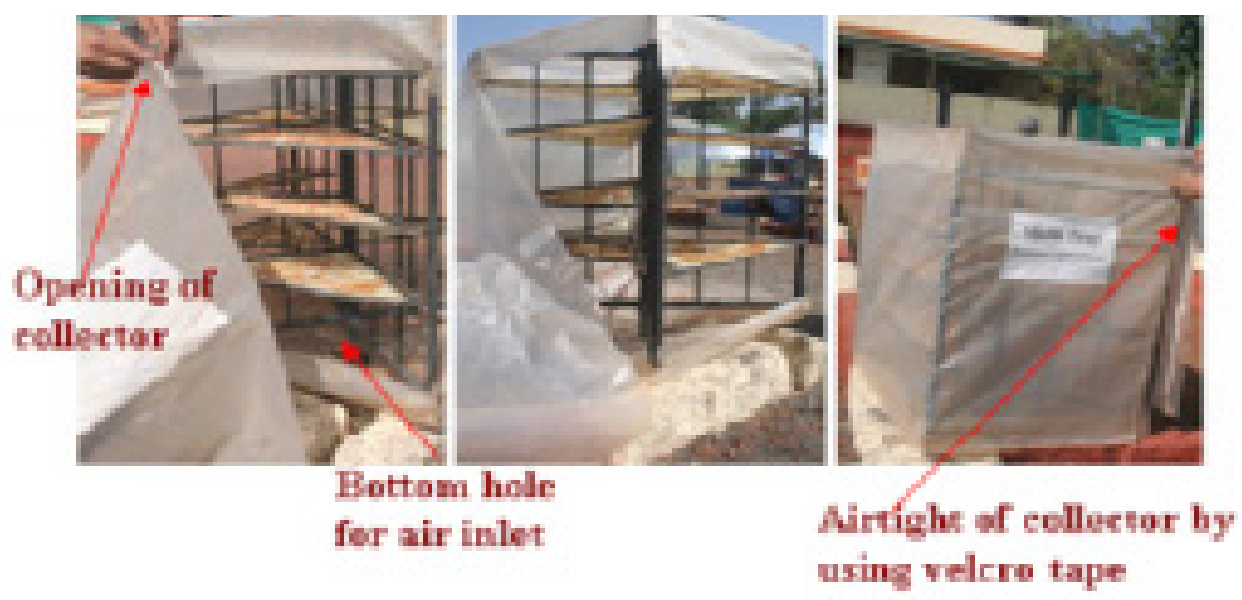

Figure 5. Low cost passive solar dryer (Sengar et al., 2009). 


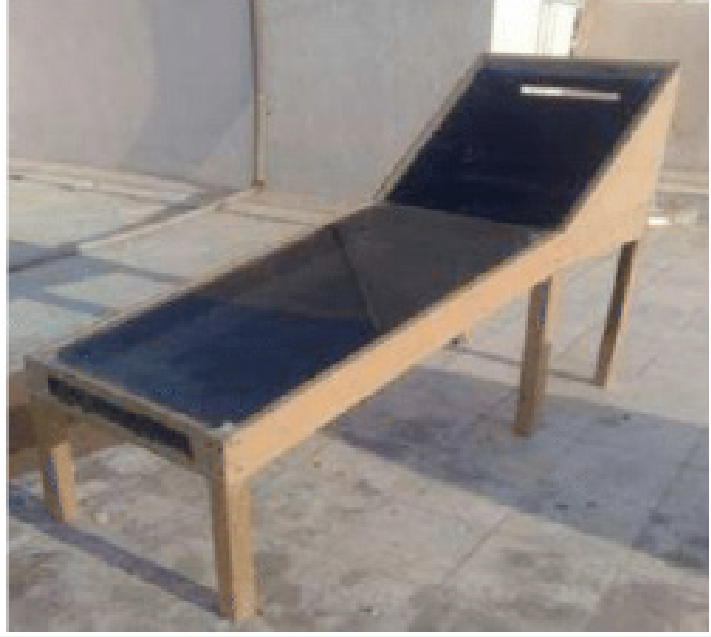

Figure 6. Fish drier diagram (Al Rawahi et al., 2013).

found that the color and texture of salted fish inside a low cost dryer were better as compared with unsalted fish, but the dried fish in open-sun was the least accepted one. In a similar study, the addition of salts in the dried fish affected positively the physical (organoleptic) properties, such as aroma, taste, texture and general acceptability. Solomon et al. (2016) observed good taste and total acceptability of salted fish were superior to those of unsalted fish when both were dried in a solar drier. Therefore, direct and indirect solar drying techniques provide better quality fish than open-sun drying and salted fish gave better physical properties than unsalted fish.

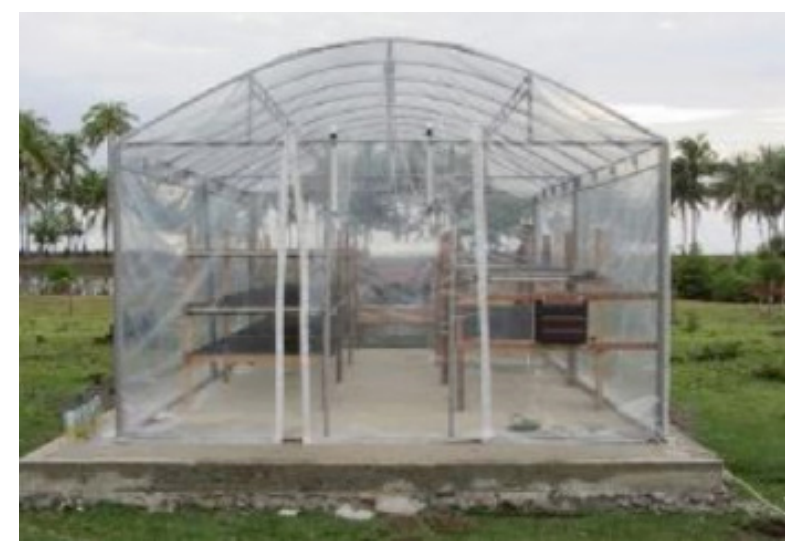

Figure 7. Force convection greenhouse solar dryer (Martunis, 2013).

For better understanding of the behavior of drying processes, regression models were extensively used. To optimize the drying process, accurate simulation-models can be to predict the performance of the product to be dried (Belessiotis and Delyannis, 2011). Non-linear regression models were used to best-fit experimental drying curves with the closest matching models. The drying rate could be either constant (fixed) or falling (decreasing), however the falling rate prevails (Toujani et al., 2013) because in most biological products, the constant rate does not exist (Bellagha et al., 2002). In the drying process, the moisture is removed rapidly at the beginning then it decreases slowly as the drying progresses. This is because at the beginning moisture evaporates from the surface of the fish and then moisture moves by diffusion inside the fish material toward the surface (Toujani et al., 2013). This behavior is described using different regression models such as exponential, logarithmic, diffusion-approximate, two-term and many others.

Hubackova et al. (2014) found that the appropriate models describing the natural convection solar drying kinetics of five species of fish were as follows; logarithmic model for climbing perch and Nile tilapia fish; diffusion-approximate model for swamp eel and walking catfish; and two-term model for channa fish. In another study, the drying kinetics of sardine muscle were well-fitted using two models, namely, exponential and page (Djendoub et al., 2009). Figure 9 illustrates the exponential drying curve of tilapia fish (Kituu et al., 2010). On the other hand, a logarithmic regression model was used to describe the drying rate of prawn and chelwa fish under open-sun drying (Jain and Pathare, 2007). In electric oven-drying, the most appropriate model for all fish species is the Modified Page1 because of the uniform drying conditions except for channa fish where the exponential model showed the best-fit. All mentioned models can help in predicting the drying kinetics of fish using different drying techniques.

\section{Health aspects of solar-dried fish}

The quality of dried fish has to meet certain characteristics with respect to protein, lipid and ash content. Recent studied proved that dried fish with high amount of protein, ash and fat content have very good nutritional value (Siddique et al., 2012). Proteins control the metabolism in the nerves and bones and control blood sugar level by producing peptides (Jónsson et al., 2007). The protein content in dried fish is higher compared to fresh fish, which is a desirable characteristic. The protein is an important factor that helps in the quality assessment of dried fish (Hazarika et al., 2016). Lipids and ash are two important sources of energy for the body. It was found that the amount of lipids is affected by the drying technique where it was reported that lipid content of open sun dried fish is less than that in fish dried with other drying methods (Anh et al., 2015). Commonly, ash content of dried fish is higher than that of fresh fish. However, it could be less in the dried fish because the ash content comes from inorganic matter, i.e. a residue that remains after drying, where water content and organic matter are reduced (Oladipo and Bankole, 2013). When the values of protein, lipids and ash content were analyzed for 10 fish species dried under open sun, they ranged 28.63-53.84, 4.42-16.52 and 8.96-30.30 g/100 g, 


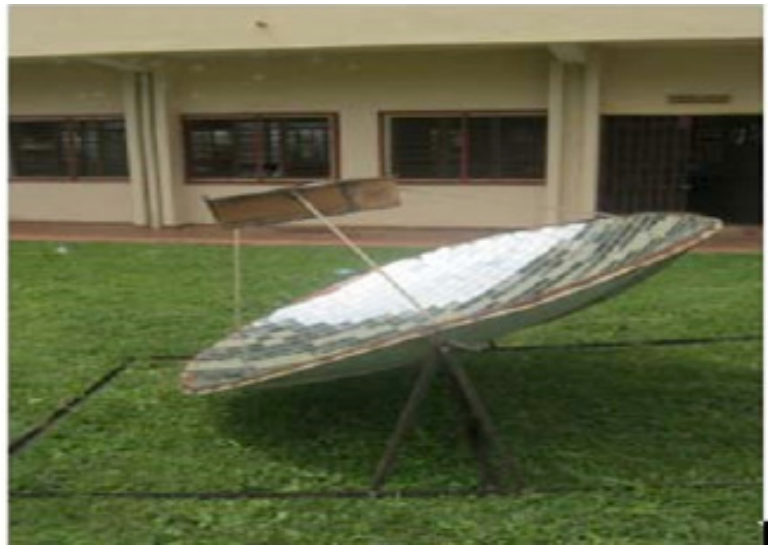

Figure 8. Parabolic-dish solar collector (Solomon et al., 2016).

respectively (Hazarika et al., 2016). In a similar study, Islam et al. (2013) reported that the protein, lipids and ash content for 4 fish types, namely, Amblypharyngodon mola (Mola), Puntius spp. (Punti), Channa punctata (Taki) and Glossogobius giuris (Bele), dried under opensun amounted to 32.02-41.38 g/100 g (Channa punctatus had the highest value), 3.21-14.03 g/100 g (Channa punctatus had the lowest value) and 20.14-24.40 g/100 g.

Sultana et al. (2008) compared the protein, lipids and ash content of fresh silver jew fish, Bombay and duck ribbon fish with the dried samples in a solar tunnel dryer. The protein content of fresh fish ranged from 65.90$71.60 \mathrm{~g} / 100 \mathrm{~g}$, lipids ranged from 13.42 to $21.30 \mathrm{~g} / 100$ $\mathrm{g}$ and ash content from 11.27 to $12.44 \mathrm{~g} / 100 \mathrm{~g}$ whereas after drying they ranged 71.9-80.52, 8.05-19.18 and 9.47-10.24 g/100 g, respectively. Similarly, Babiker et al. (2014) found that the protein, fat and ash content of dried bayad fish flakes using a natural convective solar drier were $69.19,0.23$ and $30.68 \mathrm{~g} / 100 \mathrm{~g}$ of product, respectively while, the fresh fish contained 92.51, 0.22 and $7.27 \mathrm{~g} / 100 \mathrm{~g}$ of product, respectively.

Across the developing countries, dried fish is considered a widespread delicacy. Therefore, extending the shelf life of dried fish is necessary for long time storage. To achieve this, dried fish has to meet certain characteristics such as $\mathrm{pH}$, water activity, microbial load, total volatile base nitrogen (TVB-N), trimethylamine nitrogen (TMA-N) and enzymatic autolysis which differ due to the fluctuations in processing conditions (Al Bulushi et al., 2013). Lower $\mathrm{pH}$ values of dried products offer more enhancement in microbial inhibition and consequently, increase the shelf life of dried fish by preventing endogenous proteases activities (Majumdar et al., 2017). Dried fish under a $\mathrm{pH}$ range of 6.0-6.9 are considered to be of very good quality (Kakati, 2017). This implies that the loss of fish quality can result from the increase in $\mathrm{pH}$. In literature, Puntius sophore, Setipinna phasa, Amblypharyngodon mola, Pseudeutropius atherinoides, Pseudambassis ranga and Corica soborna fish were dried under open-sun drying where the $\mathrm{pH}$ was 6.2-6.6
(Kakati.B, 2017). In another study, Noemacheilus beavani, Chanda ranga, Barilius tileo, Amphipnous cuchia, Anabas testudineus, Amblypharyngodon mola, Channa punctatus, Tor putitora, Puntius chola and Conta elongate fish were also dried under open-sun drying where most of these fish types were within the good-quality $\mathrm{pH}$ range and only four of them, viz. Amblypharyngodon mola, Channa punctatus, Tor putitora and Conta elongate, were outside the range (Hazarika et al., 2016).

The second characteristic is the water activity, which is the ratio of vapor pressure of water in the fish product to the vapor pressure of pure water at the same temperature (Labuza, 1980). The water activity is considered as a criterion and a measure of microorganism development and toxin release of enzymatic and non-enzymatic browning development. It was found that water activity greatly affects fresh fish endogenous microflora (Al Bulushi et al., 2013). There is a water activity limit for each food product below which the microorganism stop growing (Belessiotis and Delyannis, 2011). Most molds maintains their growth at a minimum water activity of 0.7 (Oparaku et al., 2017) and many bacteria sustains the growth at 0.9 , while some biogenic amines, such as E. cloacae, need water activity of 0.48 (Al Bulushi et al., 2013). Majumdar et al. (2017) found that when moisture content of dried fish is less than $15 \%$, no microbe can grow. This is because with the increase in water absorption from the surronding, the water activity increases, causing an increase in microbial growth and reduction of shelf life of dried products. Further reduction in the water activity limits the spoilage and microbial growth.

The microbial quality of fish products is affected by the drying method and the proper handling anoxic conditions (hygienic conditions) (Al Bulushi et al., 2013; Oparaku et al., 2017). Developing countries produce low microbiological quality products which could be loaded with Staphylococcus aureus, Clostridium spp. and fecal Streptococcus spp. pathogens (Al Bulushi et al., 2013). To assess the microbiological quality of fish products, Total Plate Count (TPC), which uses plate count agar, and Total Fungal Count (TFC),

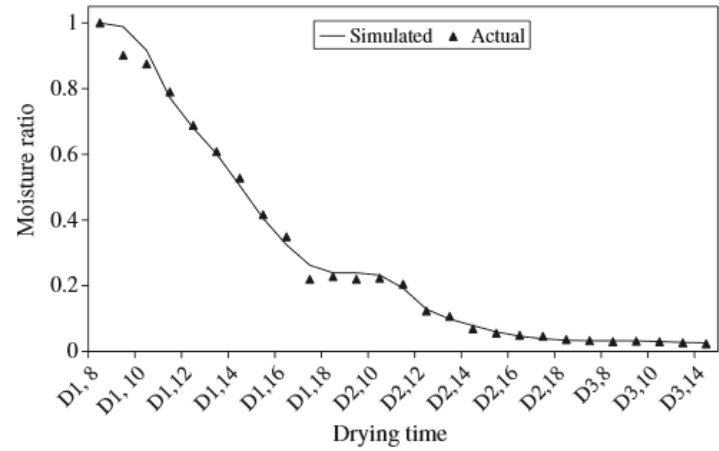

Figure 9. Exponential drying curve of tilapia fish (Kituu et al., 2010) 
which uses potato dextrose agar by APHA, are used as microbial parameters. Immaculate et al. (2012) observed that TPC and TFC were high in open-sun dried sardine but absent in the sardine dried in a solar drier. They also reported the presence of E. coli pathogens in open-sun samples, however other pathogens such as Salmonella and vibrio were absent in both methods.

Total volatile base nitrogen (TVB-N) and trimethylamine nitrogen (TMA-N) are signs (indicators) of spoilage which are correlatated strongly with the bacterial activity, endogenous enzymes and thus, the rate of spoilage (Kakati, 2017). They can be determined from trichloroacetic acid removal by micro diffusion from the sea product (fish). The recommended acceptability upper limit of these indicators for human consumption is $10-15 \mathrm{mg} / 100 \mathrm{~g}$ for TMA-N and $35-40 \mathrm{mg} / 100 \mathrm{~g}$ of TVB-N in dried fish (Immaculate et al., 2013). The quality of dried fish with respect to TVB-N can be classified into very high quality at TVB-N value of $25 \mathrm{mg} / 100 \mathrm{~g}$ or less, good quality at $26-30 \mathrm{mg} / 100 \mathrm{~g}$, limit of acceptability at $30-35 \mathrm{mg} / 100 \mathrm{~g}$ and spoilt quality above $35 \mathrm{mg} / 100 \mathrm{~g}$ (Jinadasa, 2014). However, in previous studies, the acceptablity limit for TVB-N was considered to be 100 $\mathrm{mg} / 100 \mathrm{~g}$ (Connell, 1980), which is much higher than the recent classifications. Accordingly, Hossain et al. (2017) found that TMA-N and TVB-N values of open-sun dried Silver Pomfret and open-sun dried Perch fish were within the human acceptablity levels. The TMA-N and TVB-N values for Perch dried-fish were 8.21 \pm 0.12 and $46.97 \pm 1.00 \mathrm{mg} / 100 \mathrm{~g}$, respectively and for Silver Pomfret, the values were $9.41 \pm 0.37$ and $85.68 \pm 1.60 \mathrm{mg} / 100 \mathrm{~g}$, respectively. In another study, the TVB-N value were found to be acceptable for human consumption for mola fish dried in a solar tunnel dryer $(15.68 \mathrm{mg} / 100 \mathrm{~g})$ and in open-sun $(20.36 \mathrm{mg} / 100 \mathrm{~g})$ (Islam et al., 2012). Similarly, Sultana et al. (2008) repoted that in a solar tunnel dryer, the TVB-N values of dried ribbon fish, silver jew fish and Bombay duck were ranging from 15.46 to $19.21 \mathrm{mg} / 100 \mathrm{~g}$.

The last cause of fish spoilage is the autolytic changes (Oparaku et al., 2017) which denotes the biological and chemical changes occurring because of quality losses at early stage of fresh fish (Ghaly et al., 2010; Oparaku et al., 2017). Major fish molecules undergo enzymatic breakdown and as a result of autolysis of fish muscle proteins peptides and free amino acids can be produced which cause fish meat spoilage as a result of production of biogenic amines and microbial growth (Ghaly et al., 2010). For instance, open sun dried anchovy fish was reported to contain biogenic amines that can cause scombroid-poisoning (Al Bulushi et al., 2013). The scombroid poisoning can also be caused by the increase in the level of histamine in the fish product so it is also called histamine fish poisoning (Hungerford, 2010). Bulushi et al. (2009) found that biogenic amines could be involved in the formation of nitrosamines at a high significant level when biogenic amines are present at a high concentration in fish products. It was reported, in the same study, that impure salts enhance the formation of nitrosamine whereas, pure salts (sodium chloride) inhibit nitrosamine formation.

\section{Conclusion}

A review on solar drying of fish was done, several points can be concluded from this the study: (i) Open-sun draying is the most popular preservation technique of food products, (ii) The drawbacks of open-sun drying can be overcome by implementing other solar drying techniques such as greenhouse tunnel dryers, (iii) Solar dryers have shorter drying time and higher drying rate, and the physical properties of dried fish are enhanced, (iv) Many regression models were used for better understanding of the drying processes, (v) Fish have very good nutritional value due to their high amount of proteins, lipids and ash contents, and (vi) Some characteristic, such as $\mathrm{pH}$, water activity, microbial load, total volatile base nitrogen (TVB-N), trimethylamine nitrogen (TMA-N) and enzymatic autolysis analyzes, are used to assess the quality of dried fish to achieve longer shelf life.

\section{References}

Abraha B, Samuel M, Mohammud A, Habte-Tsion HM, Admassu H, Al-Hajj, NQM. (2017). A comparative study on quality of dried Anchovy (Stelophorus heterolobus) using open sun rack and solar tent drying methods. Turkish Journal of Fisheries and Aquatic Sciences 17(6): 1107-1115. C-5:

Al-Jufaili S, Al-Jahwari OS. (2011). The Omani coastal traditional sardine fishery 1994-2007: A review. Journal of Agricultural and Marine Sciences 16: 1-12.

Al Bulushi IM, Guizani N, Dykes GA. (2013). Effect of ambient storage on the microbial characteristics of traditional dried anchovies (Encrasicholina punctifer). African Journal of Microbiology Research 7(28): 3575-3581.

Al Rawahi ZNA, Munusami A, Kaithari DK. (2013). Performance analysis of solar drying system for marine product of Oman. International Journal of Students' Research in Technology \& Management 1(6):610-613.

Anh NTN, Nhi NT, Van Hoa N. (2015). Effect of different drying methods on total lipid and fatty acid profiles of dried Artemia francis-cana biomass. Can Tho University Journal of Science 1: 1-9.

Babiker AMO, Ismail IA, Osman OE, Salih ZA. (2014). Effect of solar drying using a natural convective solar drier on bacterial load and chemical composition of bayad (Bagrus bayad) fish flakes. International Journal of Multidisciplinary and Current research 2: 2321-3124.

Bala B, Janjai S. (2009). Solar drying of fruits, vegetables, spices, medicinal plants and fish: Developments and Potentials. International Solar Food Processing Con- 
ference, Indore, India, January 14-16.

Bala B, Mondol M. (2001). Experimental investigation on solar drying of fish using solar tunnel dryer. Drying Technology 19(2): 427-436.

Basunia MA, Al-Handali HH, Al-Balushi MI, Rahman MS, Mahgoub O. (2011). Drying of fish sardines in Oman using solar tunnel dryers. Journal of Agricultural Science and Technology B 1: 108-114.

Belessiotis V, Delyannis E. (2011). Solar drying. Solar Energy 85(8): 1665-1691.

Bellagha S, Amami E, Farhat A, Kechaou N. (2002). Drying kinetics and characteristic drying curve of lightly salted sardine (Sardinella aurita). Drying Technology 20(7): 1527-1538.

Belwal R, Belwal S, Al Jabri O. (2015). The fisheries of Oman: A situation analysis. Marine Policy 61:237-248.

Bulushi IA, Poole S, Deeth HC, Dykes GA. (2009). Biogenic amines in fish: roles in intoxication, spoilage, and nitrosamine formation $-\mathrm{a}$ review. Critical Reviews in Food Science and Nutrition 49(4): 369-377.

Charters W, Macdonald R, Kaye D, Xiaoren S. (2017). Passive greenhouse type solar dryers and their development. International Energy Journal 11(2): 51-60.

Connell JJ. (1980). Control of fish quality II, Vol. 12, Fishing News Books Ltd.: 7-129.

Djendoubi N, Boudhrioua N, Bonazzi C, Kechaou N. (2009). Drying of sardine muscles: Experimental and mathematical investigations. Food and Bioproducts Processing 87(2): 115-123.

FAO. (2015). Fishery and Aquaculture Country Profiles. Oman. http://www.fao.org (accessed 7 March 2018).

Ghaly AE, Dave D, Budge S, Brooks M. (2010). Fish spoilage mechanisms and preservation techniques. American Journal of Applied Sciences 7(7): 859.

Hazarika P, Ullah N, Handique PJ. (2016). Assessment of biochemical quality of ten selected dried fish products of North East India. Assessment 3(3): 183-186.

Hossain M, Jamil M, Mia M, Uddin M, Mansur M. (2017). Studies on the proximate composition, quality and heavy metal concentration of two sun-dried marine fish (sun-dried Silver Pomfret and sun-dried Perch) of Cox's Bazar District of Bangladesh. Journal of Environmental Science and Natural Resources 10(1): 25-32.

Hubackova A, Kucerova I, Chrun R, Chaloupkova P, Banout J. (2014). Development of solar drying model for selected Cambodian fish species. The Scientific World Journal 2014. vol. 2014.10.1155

Hungerford JM. (2010). Scombroid poisoning: a review. Toxicon 56(2): 231-243.
Immaculate J, Sinduja P, Jamila P. (2012). Biochemical and microbial qualities of Sardinella fimbriata sun dried in different methods. International Food Research Journal 19(4): 1699-1703.

Immaculate K, Sinduja P, Velammal A, Patterson J. (2013). Quality and shelf life status of salted and sun dried fishes of Tuticorin fishing villages in different seasons. International Food Research Journal 20(4): 1855-1863.

Islam M, Hossain M, Mian S. (2012). Nutritive value of dried and heat processed mola fish (Amblypharyngodon mola) products. International Journal of Natural Sciences 2(2): 43-48.

Islam MT, Ahmed S, Sultana MA, Tumpa A, Flowra FA. (2013). Nutritionalandfoodqualityassessmentofdried fishes in Singra upazila under Natore district of Bangladesh. Trends in Fisheries Research 2(1): 2319-4758.

Jain D, Pathare PB. (2007). Study the drying kinetics of open sun drying of fish. Journal of Food Engineering 78(4): 1315-1319.

Jinadasa B. (2014). Determination of quality of marine fishes based on total volatile base nitrogen test (TVB-N). Nature and Science 12(5): 106-111.

Jónsson Á, Finnbogadóttir GA, Porkelsson G, Magnússon H, Reykdal Ó, Arason S. (2007). Dried fish as health food. Matis-Food Research. Innovation \& Safety Report 5: 1-22.

Kakati BK, Sharma P, Goswami UC. (2017). Quality evaluation of dried fish products commerce in Assam, india. International Journal of Advanced Biological Research 7(3): 465-469.

Kituu GM, Shitanda D, Kanali C, Mailutha J, Njoroge C, Wainaina J, Silayo V. (2010). Thin layer drying model for simulating the drying of Tilapia fish (Oreochromis niloticus) in a solar tunnel dryer. Journal of Food Engineering 98(3): 325-331.

Labuza TP. (1980). The effect of water activity on reaction kinetics of food deterioration. Food Technology 34(4): 36-41.

Majumdar BC, Afrin F, Rasul M, Khan M, Shah A. (2017). Comparative study of physical, chemical, microbiological and sensory aspects of some sun dried fishes in Bangladesh. Brazilian Journal of Biological Sciences 4(8): 323-331.

Mansur MA, Rahman S, Khan MNA, Reza MS, Uga S. (2013). Study on the quality and safety aspect of three sun-dried fish. African Journal of Agricultural Research 8(41): 5149-5155.

Martunis M. (2013). Performance of a forced-convection greenhouse dryer for fish drying. Rona Teknik Pertanian 6(1): 426-430. 
Mustapha MK, Ajibola TB, Salako AF, Ademola SK. (2014). Solar drying and organoleptic characteristics of two tropical African fish species using improved low-cost solar driers. Food Science \& Nutrition 2(3): 244-250.

Ochieng OB, Oduor OPM, Nyale MM. (2015). Biochemical and nutritional quality of dried sardines using raised open solar rack dryers off Kenyan coast. Journal of Food Resource Science 4(2): 33-42.

Oladipo I, Bankole S. (2013). Nutritional and microbial quality of fresh and dried Clarias gariepinus and Oreochromis niloticus. International Journal of Applied Microbiology and Biotechnology Research 1: 1-6.

Oparaku NF, Mgbenka BO, Eyo JE. (2017). Proximate and organoleptic characteristics of sun and solar dried fish. Animal Research International 7(2): 1169-1175.

Prakash O, Kumar A. (2014). Solar greenhouse drying: A review. Renewable and Sustainable Energy Reviews 29: 905-910.

Sahu TK, Jaiswal V, Singh AK. (2016). A review on solar drying techniques and solar greenhouse dryer. IOSR Journal of Mechanical and Civil Engineering 13:31-37.

Sengar S, Khandetod Y, Mohod A. (2009). Low cost solar dryer for fish. African Journal of Environmental Science and Technology 3(9).

Siddique M, Mojumder P, Zamal H. (2012). Proximate composition of three commercially available marine dry fishes (Harpodon nehereus, Johnius dussumieri and Lepturacanthus savala). American Journal of Food Technology 7(7): 429-436.
Singh P, Shrivastava V, Kumar A. (2017). Recent developments in greenhouse solar drying: A review. Renewable and Sustainable Energy Reviews 82: 3250-3262.

Solomon S, Okomoda V, Egwumah A. (2016). Design and performance of a pioneering solar collector using parabolic dish for fish processing. Jordan Journal of Agricultural Sciences 12(2): 581-590.

Sontakke MS, Salve SP. (2015). Solar drying technologies: A review. International Journal of Engineering Science 4: 29-35.

Sultana S, Hossain M, Shikha F, Islam M, Kamal M. (2008). Quality assessment of rotating and solar tunnel dried marine fish product. Bangladesh Journal of Fisheries Research 12(1): 121-128.

Tiwari G, Das T, Chen C, Barnwal P. (2009). Energy and exergy analyses of greenhouse fish drying. International journal of exergy 6(5): 620-636.

Toujani M, Hassini L, Azzouz S, Belghith A. (2013). Experimental study and mathematical modeling of silverside fish convective drying. Journal of Food Processing and Preservation 37(5): 930-938.

Walters SA, Jha AK. (2016). Sustaining chili pepper production in Afghanistan through better irrigation practices and management. Agriculture 6(4): 62-71. 